\title{
Synthesis and Characterization of New Compounds Derived from N-(mono chloro) Adipoyl Phthalimide
}

\author{
Zena G. Alrekabi \\ Chemistry department, College of Science, Baghdad University, Baghdad, Iraq
}

\begin{abstract}
This work contain preparation new compounds derived from $\mathrm{N}$-(mono chloro) adip phthalimide (1) in three steps, the first step was prepare Schiff bases compounds from the reaction of $\mathrm{N}$ hydrazino adip phthalimide (2) with different aldehydes and ketones. The second step was prepared thiazolidine ring by the reaction of prepared Schiff bases with mercapto acetic acid. The third step was included preparation of imide ring by react compound (2) with different anhydrides in presence of glacial acetic acid. All the prepared compounds were characterized by FT-IR spectra, some of them by $\mathrm{H}^{1}$-NMR, physical properties and measurements of thermal stability by TG. technique.

[DOI: $10.22401 /$ ANJS.00.2.02]
\end{abstract}

Keywords: Adipoyl chloride, Thiazolidine, Phthalimide.

\section{Introduction}

The reaction of potassium salt of phthalimide with excess amount of adipoyl chloride give mono substituted acid chloride, this compound is very active to inter nucleophilic substitution reaction with hydrazine hydrate to gate acid hydrazide, [1]. variety of aromatic and aliphatic aldehydes and ketones react with acid hydrazide to produce Schiff bases, most of these compounds and their complexes have many application including biological, clinical and analytical, [2-4].

On the other hand Schiff bases compounds can be consider as intermediates to obtain some important heterocyclic compounds which are a class of organic compounds that exert a wide range of biological activities, [5-6].

It is well known that heterocyclic compounds having azole nucleus are important pharmacophore that appear extensively in various types of pharmacological activities, these heterocyclic compounds form a major part of organic chemistry, They are widely distributed in nature and play a vital role in metabolism of living Cells, [7]. The development of simple synthetic routes to widely used organic compounds of 4-oxo thiazolidine [8] and pyrolidine 1,4-dione derivatives, [9]. These compounds are found to be associated with various biological activities and the antimicrobial activity of some selected products was evaluated and showed good results like some important organosulfur drugs, [10].

\section{Material and instruments}

The chemicals used in this work were from BHD and fluka and used without further Purification. Melting points were determined on Gallenkamp capillary melting point Apparatus and were uncorrected. FTIR spectra were recorded using $\mathrm{KBr}$ discs on SHIMADZU FTIR-8400 Eourier Transform infrared spectrophotometer. H-NMR spectra were recorded on Nuclear magnetic resonance Bruker, ultasheiled 500MHZ in Iran using tetra methyl saline as internal Standard, DMSO-d6 and CDCI3 as solvents.

\section{Experimental part}

\section{Preparation of potassium phthalimide salt:}

Potassium hydroxide $(0.01$ mole, $0.56 \mathrm{~g})$ was dissolve in ethanol $(15 \mathrm{ml})$ then added this solution to $(0.01$ mole, $1.4 \mathrm{~g})$ from phthalimide with stirring, filter the precipitate and dried it.

\section{Preparation of $\mathrm{N}$-mono chloro adipoyl phthalimide (1):}

Dissolved the potassium salt of phthalimide in 1,4 dioxan ( 0.01 mole, $1.8 \mathrm{~g}$ ) in $(15 \mathrm{ml})$ then added to excess amount of adipoyl chloride( 0.02 mole, $2.6 \mathrm{~g})$,escalation 
for an hour, after evaporation of solvent and cooling, filter the precipitate and recrystallized from absolute ethanol.

\section{Preparation of $\mathrm{N}$ - (hydrazino) adip phthalimide (2), [11]:}

Dissolved (2 $\mathrm{gm})$ of adipoyl chloride derivative $(1)$ in $(15 \mathrm{ml})$ of ethanol then added $(0.68 \mathrm{gm})$ of tri ethyl amine and $(0.33 \mathrm{gm})$ of hydrazine hydrate, the mixture undergo reflux for $3 \mathrm{hr}$. in water bath, after that filter the solution to remove the salt and cooling the filtrate until the acid hydrazide derivative precipitate and recrystallized from ethanol.

\section{Preparation of schiff bases from $N$ - \\ (hydrazino) adip phthalimide, [12]:}

(0.001 mole) of acid hydrazide derivative was dissolved in $(15 \mathrm{ml})$ of ethanol and added a few drops of a glacial acetic acid with various aldehydes or ketones $(0.001 \mathrm{~mol})$ the mixture was dissolved in suitable amount of ethanol and heated at (70-80) c for $4 \mathrm{hr}$., after cooling the precipitate was separated, filtered and recrystallized from ethanol. (Physical properties are listed in table A).

\section{Preparartion of $\mathrm{N}$-(2-substituted-4- oxo-}

\section{1,3- thiazolidine) aip phthalimide, [13]:}

In around bottomed flask placed $(0.003$ mole) of prepared Schiff bases in (4) and 2mercapto acetic acid (0.003 mole), the mixture was refluxed in $(20 \mathrm{ml})$ of dry benzene for 6hr.,evaporated the excess of solvent and neutralized the residue with cold dilute sodium bi carbonate solution, the formed precipitate was filtered and recrystallized from ethanol.

\section{Preparation of $N$ - ( $N$-Alkyl imidyl mono adipoyl amido ) phthalimide, [14]:}

The mixture of hydrazide derivative (2) $(0.0017 \mathrm{~mol})$ with different anhydrides $(0.0017 \mathrm{~mol})$ dissolved in $(10 \mathrm{ml})$ of glacial acetic acid, refluxed the mixture for (7-8) hr., then cooling the solution by adding it to ice water, the formed precipitate was filtered and recrystallized from suitable solvent.

\section{Results and Discussion}

Cyclic imides like succinimide, phthalimide and maleimide have found to be an important moiety in creation of novel medical materials, [15]. So the preparation of $\mathrm{N}$-mono chloro adipoyl phthalimide (1) from potassium phthalimide and adipoyl chloride is very important to convert $t$ to other derivatives. the spectroscopic identification of compound (1) such as (FT-IR) spectrum showed characteristic absorption bands at $2921 \mathrm{~cm}^{-1}, 3088 \mathrm{~cm}^{-1}, 1771 \mathrm{~cm}^{-1}, 1693$ $\mathrm{cm}^{-1}, 1601 \mathrm{~cm}^{-1}, \quad 734 \mathrm{~cm}^{-1}$ due to $\sqrt{ }(\mathrm{C}-\mathrm{H})$ aliphatic, $(\mathrm{C}-\mathrm{H})$ aromatic, $\sqrt{ }(\mathrm{C}=\mathrm{O})$ acid chloride and $(\mathrm{C}=\mathrm{O})$ imide, $\sqrt{ }(\mathrm{C}-\mathrm{N})$ and $\sqrt{ }(\mathrm{C}-\mathrm{Cl})$ respectively as showed in (table $\mathrm{B})$.

$\mathrm{H}^{1}$-NMR spectrum for compound (1) showed signal in $\delta=(7.32-7.94) \mathrm{ppm}$ due to $(\mathrm{m}, 4 \mathrm{H}$, Ar-H) $\mathrm{f}$ and triplet Signal in $\delta=(3.35) \mathrm{ppm}$ due to $\left(\mathrm{t}, 2(2 \mathrm{H}), \underline{\mathrm{CH}}_{2} \mathrm{C}=\mathrm{O}\right)$ and multi signal in $\delta=(2.15)$ ppm due to (m,2(2H), $\left.\mathrm{CH}_{2} \underline{\mathrm{CH}_{2}} \mathrm{CH}_{2}\right)$ protons as shown in Fig.(4)

Compound (1) is very active towards nucleophilic reagents such as $-\mathrm{OR},-\mathrm{NH}_{2}$ and $\mathrm{NHNH}_{2}$, which is easily to react with hydrazine hydrate to give $\mathrm{N}$-(hydrazino)adip phthalimide (2) this compound was identified by its physical properties (table A )and by spectral methods FT-IR and $\mathrm{H}^{1}$-NMR.

The FT-IR spectrum of compound (2) show appearance of two bands at the range (3300-3197) $\mathrm{cm}^{-1}$ for $\left(-\mathrm{NH}_{2}\right)$ of hyddrazino group and (1748) $\mathrm{cm}^{-1}$ for $(\mathrm{C}=0)$ groups, $(\mathrm{C}-\mathrm{H})$ aliphatic at $(2920) \mathrm{cm}^{-1}$ and $(\mathrm{C}-\mathrm{H})$ aromatic at (3089) $\mathrm{cm}^{-1}$, [16].

$\mathrm{H}^{1}$-NMR spectrum for compound(2) showed doublet signal in $\delta=(2.48) \mathrm{ppm}$ due to $(\mathrm{d}, 4 \mathrm{H})$ in $\left(\mathrm{CH}_{2}\right)_{4}$ protons, doublet signal in $\delta=(3.31)$ ppm due to $(\mathrm{d}, 2 \mathrm{H})$ in $\mathrm{NH}_{2}$ protons and signals in $\delta=(7.81) \mathrm{ppm}$ due aromatic ring protons.

Schiff bases the new derivatives of $\mathrm{N}$ (hydrazino) adipphthalimide (2) can be prepared from condensing compound (2) with many aldehydes and ketones in presence of glacial acetic acid, these Schiff bases compounds $(3,5,7,9)$ were isolated and characterized by melting points and spectroscopic data (tables A and B).

The compounds $(3,5,7,9)$ were reacted with mercapto acetic acid in dry benzene As a solvent to give four new heterocyclic derivatives of adip phthalimide. Compounds $(4,6,8,10)$ are these new compounds derived from $\mathrm{N}$-(2-substituted-4-oxo-1,3-thiazolidine) adip phthalimide, these compounds were isolated and Identified by physical properties and spectral methods. 
Scheme (1) showing the steps of preparation:

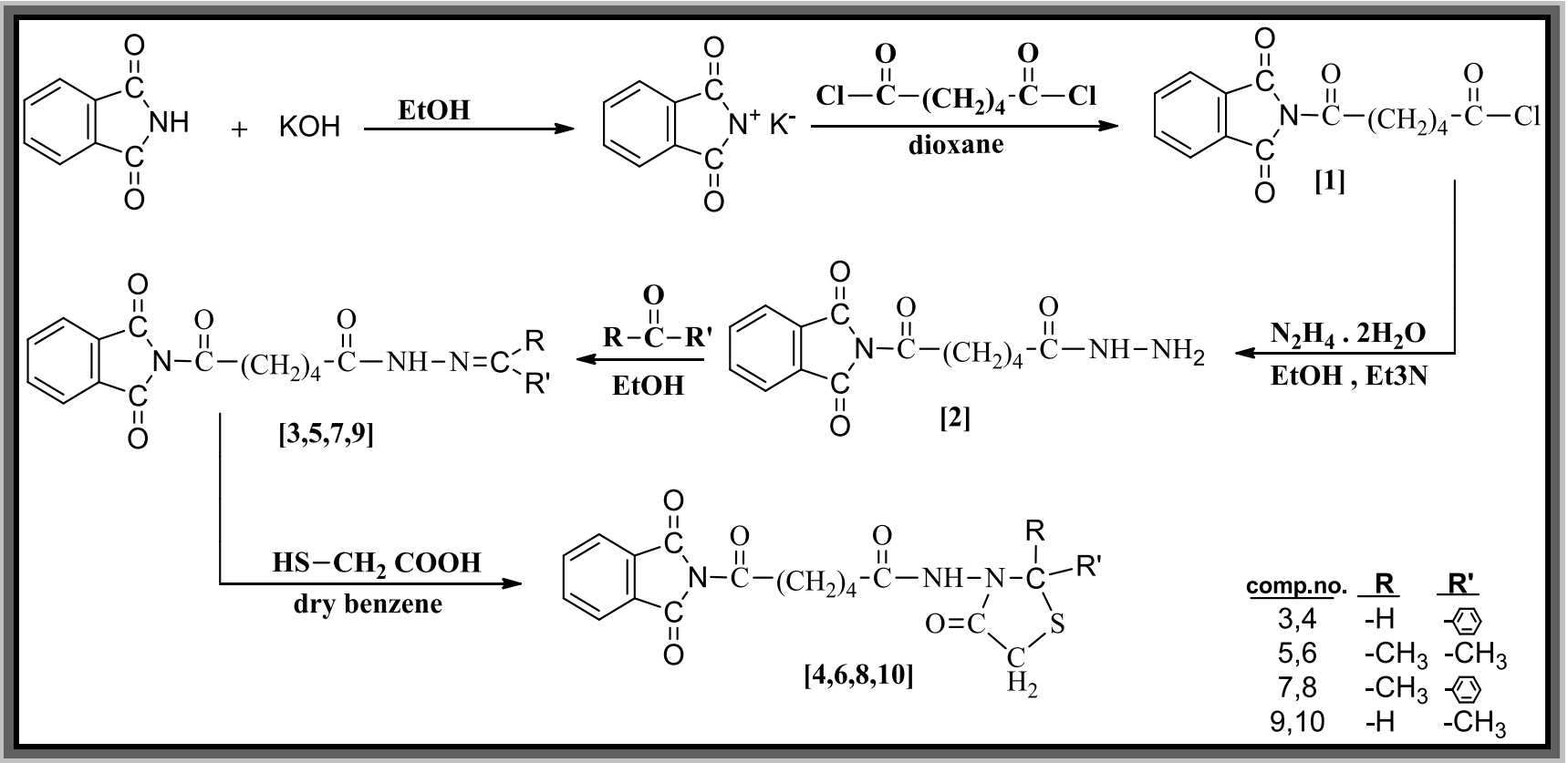

\section{Scheme 1}

The third line in this work include reaction between compound (2) and different anhydrides to give $\mathrm{N}$-( $\mathrm{N}$-alkyl imidyl mono adipoyl amido) phthalimide. This step using glacial acetic acid as a solvent and a catalyst, the compounds $(11,12,13,14)$ were characterized by FT-IR spectra which showing disappearance one of two bands of $\mathrm{NH}_{2}$ group. The stability of these compounds in high temperature was studied through thermal gravimetric analysis (TG).as shown in figures (7)-(9).

Scheme (2) show the preparation of compounds $(11,12,13,14)$ :

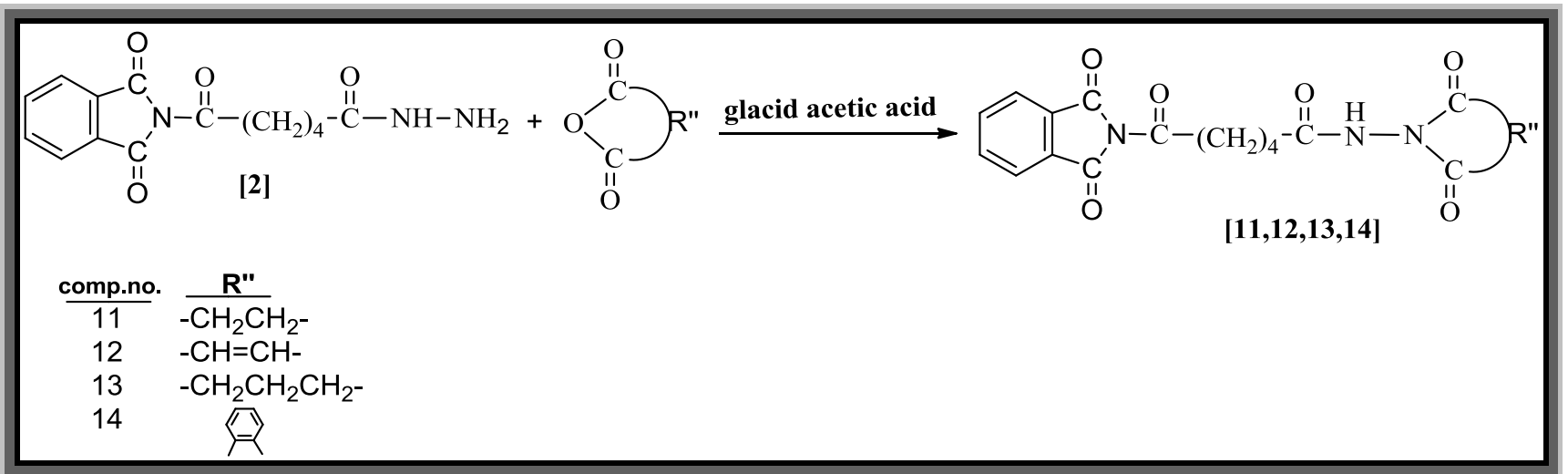

Scheme (2) 
Table (A)

The physical properties of prepared compounds

\begin{tabular}{|c|c|c|c|c|c|}
\hline Com.No. & Structures & Color & M.P. C & Yield \% & Recr. Sol. \\
\hline 1 & & Gray & 160 & 93 & methanol \\
\hline 2 & & White & 220 & 80 & ethanol \\
\hline 3 & & White & 230 & 54 & ethanol \\
\hline 4 & & Pale blue & 236 & 82 & benzene \\
\hline 5 & & Off white & 241 & 57 & ethanol \\
\hline 6 & & White & 250 & 84 & benzene \\
\hline 7 & & Brown & 230 & 60 & ethanol \\
\hline 8 & & White & 202 & 84 & benzene \\
\hline 9 & & Brown & 138 & 52 & ethanol \\
\hline 10 & & White & 280 & 81 & benzene \\
\hline 11 & & White & 208 & 95 & methanol \\
\hline 12 & & White & 236 & 94 & methanol \\
\hline 13 & & White & 242 & 94 & ethanol \\
\hline 14 & & white & 251 & 95 & ethanol \\
\hline
\end{tabular}


Table (B)

The values of FT-IR spectra for prepared compounds

\begin{tabular}{|c|c|c|c|c|c|c|c|}
\hline \multirow{2}{*}{$\begin{array}{l}\text { Com. } \\
\text { No. }\end{array}$} & \multirow[b]{2}{*}{ Structures } & \multicolumn{6}{|c|}{ FTIR spectral data $\mathrm{cm}^{-1}$} \\
\hline & & $\begin{array}{c}v(C-H) \\
\text { aliphatic } \\
\end{array}$ & $\begin{array}{c}\nu(\mathrm{C}-\mathrm{H}) \\
\text { aromatic } \\
\end{array}$ & $v(C=0)$ & $v(\mathbf{N}-\mathbf{H})$ & $v(\mathrm{C}-\mathrm{O})$ & Others \\
\hline 1 & & $\begin{array}{l}2921 \\
2847\end{array}$ & 3088 & $\begin{array}{l}1771 \\
1693\end{array}$ & - & 1193 & $\begin{array}{c}734 \\
v(\mathrm{C}-\mathrm{Cl})\end{array}$ \\
\hline 2 & & $\begin{array}{l}2920 \\
2855\end{array}$ & 3089 & $\begin{array}{l}1774 \\
1691\end{array}$ & 3197 & 1182 & $\begin{array}{c}3300 \\
v\left(\mathrm{NH}_{2}\right)\end{array}$ \\
\hline 3 & & $\begin{array}{l}2918 \\
2854\end{array}$ & 3093 & $\begin{array}{l}1774 \\
1650\end{array}$ & 3184 & 1182 & $\begin{array}{c}1602 \\
v(\mathrm{C}=\mathrm{N})\end{array}$ \\
\hline 4 & & $\begin{array}{l}2921 \\
2852\end{array}$ & 3083 & $\begin{array}{l}1748 \\
1650\end{array}$ & 3203 & 1139 & $\begin{array}{c}646 \\
v(\mathrm{C}-\mathrm{S})\end{array}$ \\
\hline 5 & & $\begin{array}{l}2923 \\
2852\end{array}$ & 3089 & $\begin{array}{l}1751 \\
1643\end{array}$ & 3199 & 1139 & $\begin{array}{c}1602 \\
v(\mathrm{C}=\mathrm{N})\end{array}$ \\
\hline 6 & & $\begin{array}{l}2920 \\
2852\end{array}$ & 3082 & $\begin{array}{l}1749 \\
1640\end{array}$ & 3201 & 1137 & $\begin{array}{c}646 \\
v(\mathrm{C}-\mathrm{S})\end{array}$ \\
\hline 7 & & $\begin{array}{l}2920 \\
2850\end{array}$ & 3064 & $\begin{array}{l}1751 \\
1641\end{array}$ & 3195 & 1139 & $\begin{array}{c}1602 \\
v(\mathrm{C}=\mathrm{N})\end{array}$ \\
\hline 8 & & $\begin{array}{l}2922 \\
2855\end{array}$ & 3093 & $\begin{array}{l}1748 \\
1642\end{array}$ & 3200 & 1137 & $\begin{array}{c}648 \\
v(\mathrm{C}-\mathrm{S})\end{array}$ \\
\hline 9 & & $\begin{array}{l}2919 \\
2855\end{array}$ & 3090 & $\begin{array}{l}1750 \\
1642\end{array}$ & 3199 & 1140 & $\begin{array}{c}1600 \\
v(\mathrm{C}=\mathrm{N})\end{array}$ \\
\hline 10 & & $\begin{array}{l}2920 \\
2854\end{array}$ & 3093 & $\begin{array}{l}1740 \\
1643\end{array}$ & 3220 & 1137 & $\begin{array}{c}640 \\
v(\mathrm{C}-\mathrm{S})\end{array}$ \\
\hline 11 & & $\begin{array}{l}2918 \\
2850\end{array}$ & 3093 & $\begin{array}{l}1763 \\
1691\end{array}$ & 3199 & 1139 & $\begin{array}{c}1485 \\
v(\mathrm{~N}-\mathrm{N})\end{array}$ \\
\hline 12 & & $\begin{array}{l}2920 \\
2852\end{array}$ & 3093 & $\begin{array}{l}1749 \\
1691\end{array}$ & 3197 & 1137 & $\begin{array}{c}1463 \\
v(\mathrm{~N}-\mathrm{N})\end{array}$ \\
\hline 13 & & $\begin{array}{l}2921 \\
2854\end{array}$ & 3097 & $\begin{array}{l}1749 \\
1691\end{array}$ & 3193 & 1139 & $\begin{array}{c}1463 \\
v(\mathrm{~N}-\mathrm{N})\end{array}$ \\
\hline 14 & & $\begin{array}{l}2920 \\
2850\end{array}$ & 3091 & $\begin{array}{l}1745 \\
1693\end{array}$ & 3201 & 1139 & $\begin{array}{c}1465 \\
v(\mathrm{~N}-\mathrm{N})\end{array}$ \\
\hline
\end{tabular}




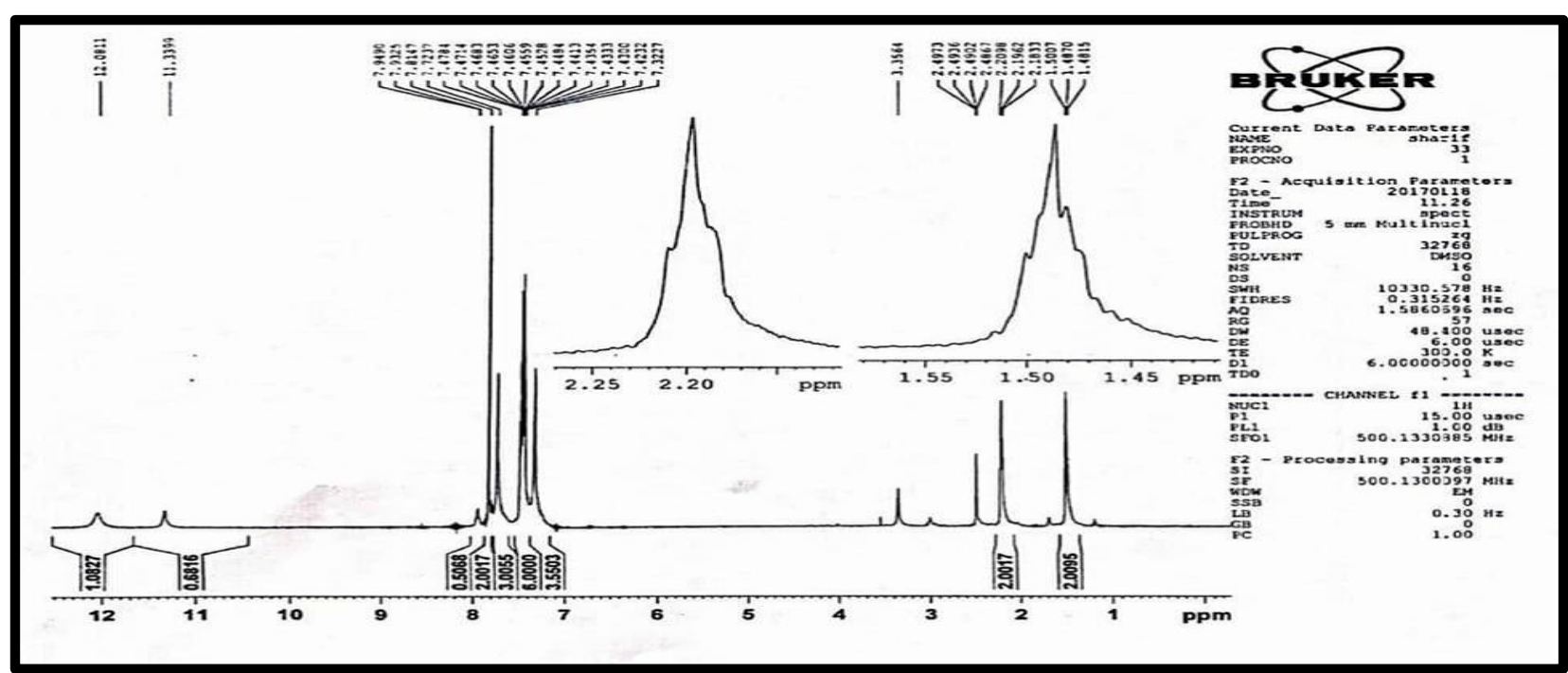

Fig.(1) The ${ }^{I} H$-NMR spectrum of compound (1).

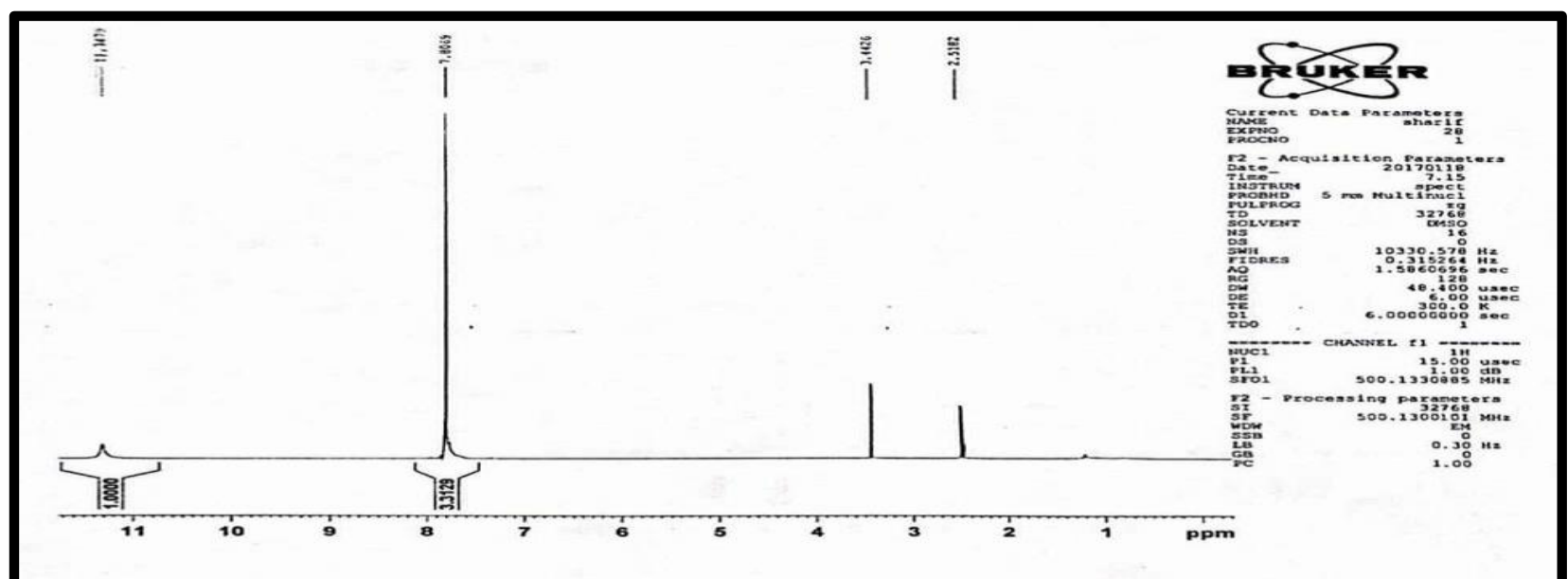

Fig. (2) The ${ }^{I} H-N M R$ spectrum of compound (2).

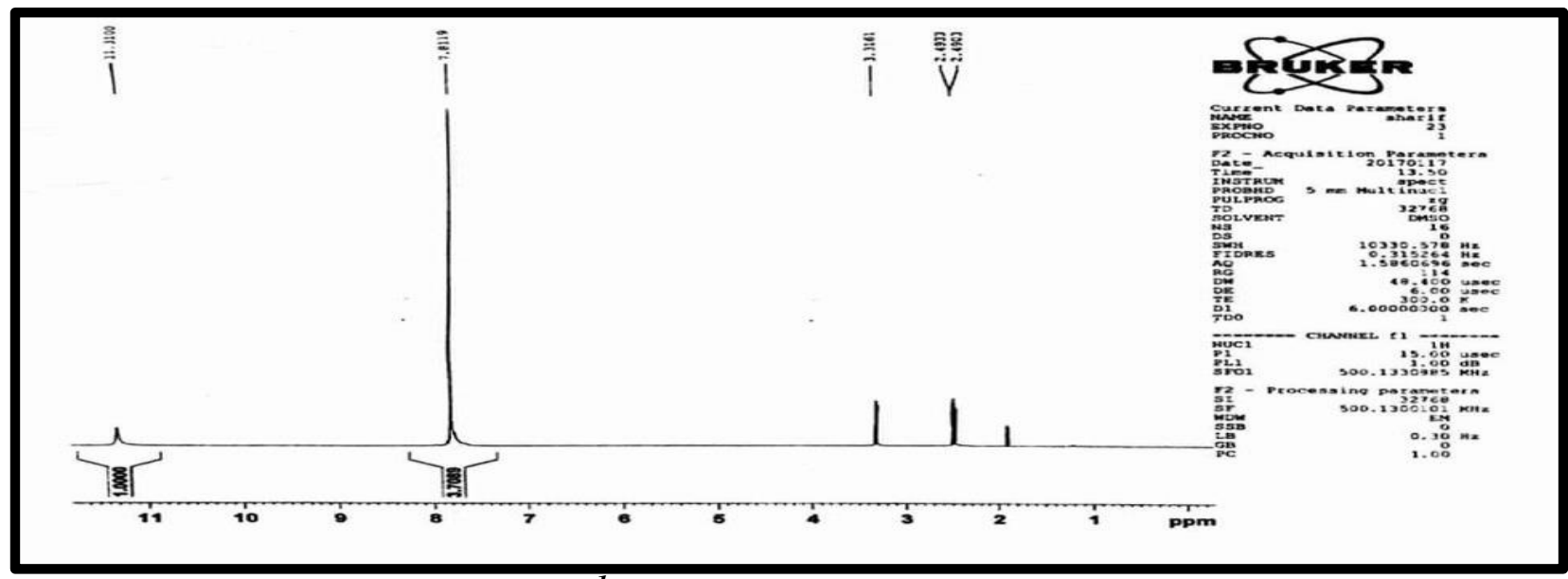

Fig. (3) The ${ }^{1}$ H-NMR spectrum of compound (4). 


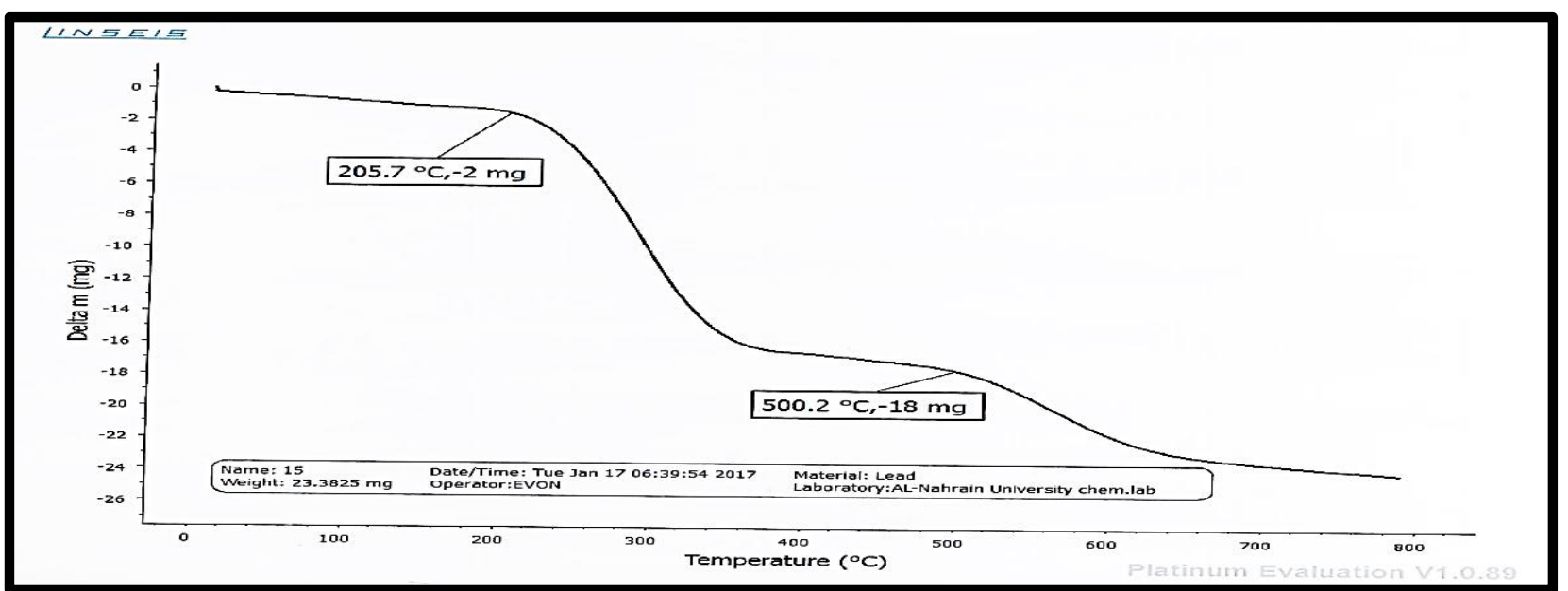

Fig. (4) The TG. Analysis for compound (14).

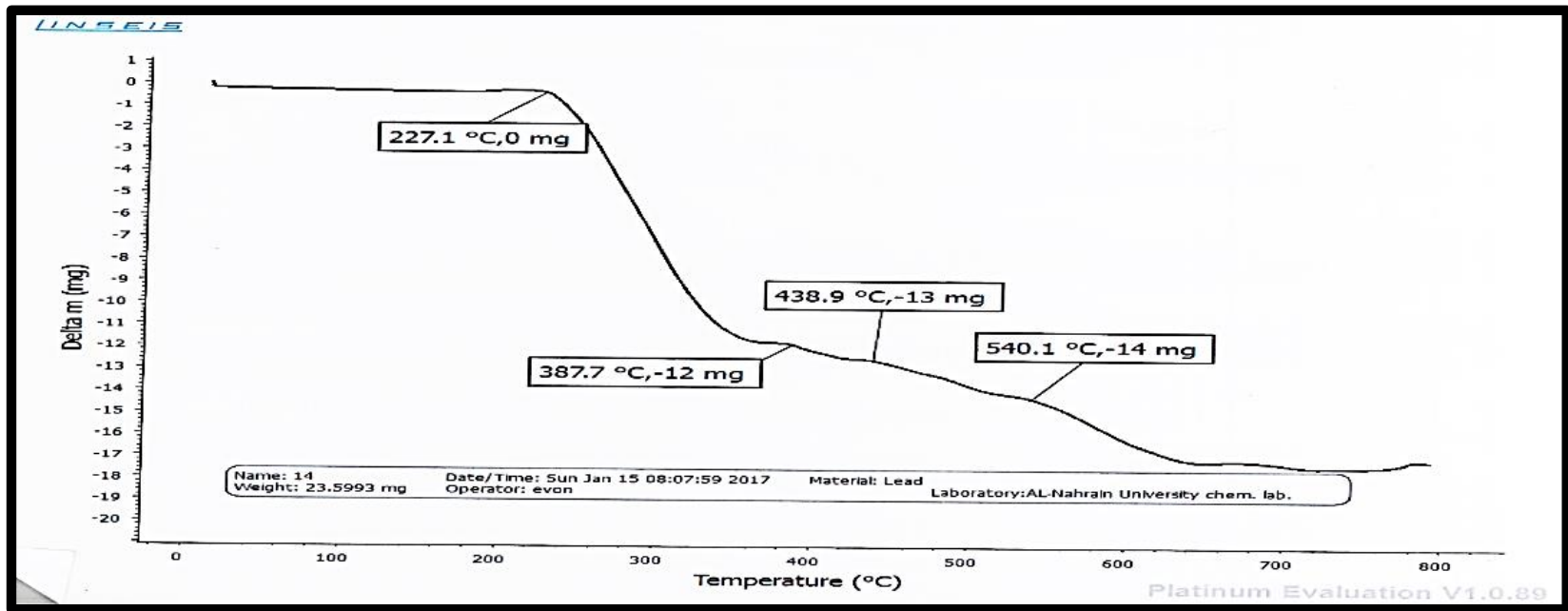

Fig. (5) The TG. Analysis for compound (13).

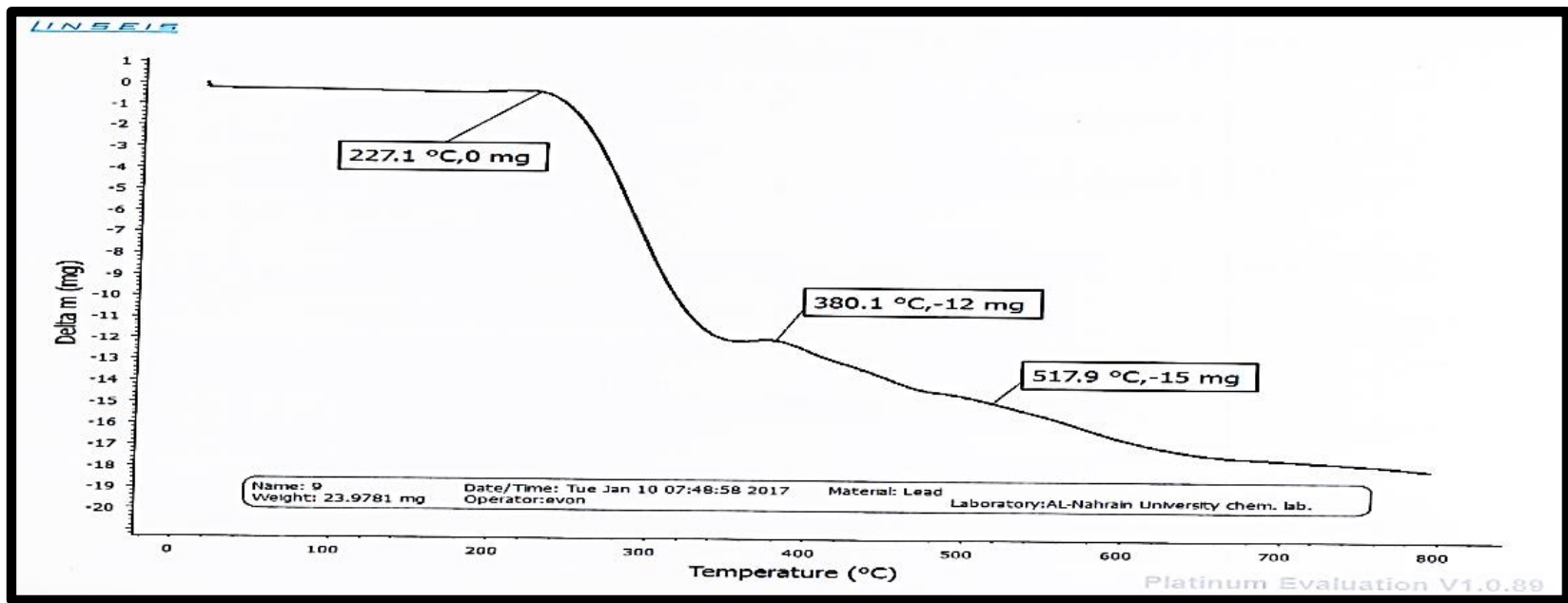

Fig. (9) The TG. Analysis for compound (8).

\section{References}

[1] Al-Dhaief, Y. A. "Synthesis of new piprazine derivatives containing 1,3,4triazole and 1,3,4-oxadiazole rings"; M.Sc. Thesis, Al-Nahrian University (1999).
[2] Cimerman, Z., Miljanie, S. and Galic, N. "Schiff Bases Derived from Amino pyridine as fluorimetric Ananlytical Reagents", Croatica Chemical Acta; Vol.73 (1); P.81-95, (2000).

[3] Perry, B.F. Beeze, A.E. Miles, R.J. Smith, B.V. Miller, J. and Nascimento. D. A. 
Graz "Evaluation of micro calorimetry as a drug bioactivityScreening procedure: application to aseries of novel Schiff baseCompounds", Microbios, Vol.45 (184-185); P.181-191; (1998).

[4] Kabak, M. Elmal, and Elerman. Y. "Ketoenol-Tautomerism Conformations and structure of N-(2-Hydroxy-5-Methyl phenyl, 2-Hydroxy benzaldehydeimine", J. Mol structure Vol.477(1-3); 151-158; (1999).

[5] Ezabadi, I. R.; Camoutsis, C.; Zoumpou Lakis; P.; Geronikaki, A.; Sokovic M., Glamocilita, J. and Ciric A., Bioorg. Med. Chem., Vol.(16), P.1150-1161; (2008).

[6] Entesar O. Al-Tamimi, Sameaa J. AlBayati "Synthesis and Polymer Product with alkyl halide"; Baghdad Science Journal; Vol.7 (1), P.631-640; (2010).

[7].Jie, L. I. Jack "Hetero cyclic chemistry in drug discovery", New York, Wiley-ISDN 9781118354421 (2013).

[8] Al-Omran, F.; Mohareb, R. M.; Abou ElKhair, A. "Synthesis and Biological effects of new derivatives of benzothiazole as antimicrobial and antifungal agents", J. Hetero cyclic chem. Vol.39, P.877-883, (2002).

[9] Harreus Albrecht Ludwing "Pyrrole"; Ulmanns Encyclopedia of industrial chemistry weinheim, Wiley-VCH, (2005).

[10] Patel. A. A, Mehta G. A.; "Per Pharma chemical"; Vol.2 (1), P.215, (2010).

[11] Kamal El-Deen A. M., R. Shaker, A. A. Abo El-Hassan and F. F. Abdel Latif "Synthesis of some thienotetra hydro quinolone derivatives"; Journal of Chinese chemical society, Vol.(51); P.335-345; (2004).

[12] Fuson S., Curth Morrill "the systematic identification of organic compounds"; sixth edition, P.179; (1980).

[13] J. Tomaa, H. "Synthesis and characterization of novel Schiff bases cantaining isooxazoline or pyrazoline unit" ibn Al-Haithem J. for pyre and Appl. SCL; Vol.24 (2), P.167; (2011).

[14] Suaaad M. H. Al-Majidi and Redhab A. "Synthesis and evaluation anti micro bial activity of some new S-substituted
Quinazoline containing pentagonal and Hexagonal heterocyclic rings", Journal of Zanko Sulaimani; Vol. 17(1); P.33-48; (2015).

[15] Andricopulo, A. D.; Yanes, R. A. and Filho, V. C. Pharmazie, Vol.(54), P.698; (1999).

[16] R. M. Solverstein, F. X. Webster. D. J. Kiemle "Spectrometric identification of organic compounds", $7^{\text {th }}$ ed., John Wiley and Sons. Inc.; (2005). 